\title{
Urban flooding in Britain: an approach to comparing ancient and contemporary flood exposure
}

\author{
T. E. O'Shea ${ }^{1}$ (D) J. Lewin ${ }^{2}$
}

Received: 15 March 2018 / Accepted: 13 July 2020 / Published online: 24 July 2020

(c) The Author(s) 2020

\begin{abstract}
Using modified UK Environment Agency Flood Estimation Handbook techniques, inundation extent and likely flood hydrographs for $0.1 \%$ probability annual return periods are compared for twelve Roman town sites in the UK, both at the present day and for simulated Roman catchment conditions. Eight of the study sites appear to have suffered minimal urban flood liability as occupied in the Roman period. The exceptions were Canterbury, York, Leicester, and Chichester. It is reasonable to expect flood characteristics to have changed subsequently in response to transformations in catchment land use, urban expansion, wetland reclamation, and floodway engineering. However, modelling results suggest limited differences in flood flows attributable to such factors. Greater present-day urban damage liability essentially results from floodplain urban extension. There are also contrasts between sites: those Roman towns lying on floodplains themselves, rather than on slightly elevated terraces (Canterbury, Chichester), are dominated by groundwater regimes with attenuated flood peaks. Taken together, these results suggest some Roman awareness of the actualities of urban flood liability at the time. Site sensitivity has not been carried forward as urban expansion has flourished, especially from the nineteenth century with suburban and industrial expansion. The straightforward mapping approach here suggested should in future take account of multiple century-scale hydroclimatic changes, morphological river channel and floodplain transformations over similar time periods, and on-going improvements to inundation modelling.
\end{abstract}

Keywords Flood inundation · Roman settlements · Hazard perception · Evolution of risk · Historical vulnerability

\section{Introduction}

The cores of many UK urban towns and cities date back to Romano-British and Saxon times (Russo 1998). Colonia were established for Roman citizens by Roman imperial decree (present-day Colchester, Lincoln, Gloucester and York); a municipium was

T. E. O'Shea

t.oshea@bristol.ac.uk

School of Geographical Sciences, University of Bristol, Bristol, UK

2 Department of Geography and Earth Sciences, Aberystwyth University, Aberystwyth, UK 
established at Verulanium related to a prior native settlement, and possibly at other sites; numerous civitas were established as local tribal capitals (mostly on the sites of strategically-placed Roman forts); and there were also vici, small towns of which some eighty are now known. Many of these declined or were abandoned in post-Roman times, but were subsequently redeveloped, with the further addition of wics (trading and industrial centres that developed into places like present-day Ipswich and Southampton) in Anglo-Saxon times. Stronghold burhs followed, initially in Wessex during the Viking wars, some at Roman sites with others elsewhere.

For both military and trading reasons, many of these early urban foundations were strategically sited next to rivers and river crossings. Without careful site selection, they were thus liable to the hazard of flooding. Such risks have become greatly exacerbated over the centuries as urban centres have expanded across and modified the rivers and floodplains next to them (Lewin 2010, 2013). The Romans themselves were certainly well aware of environmental hazards such as volcanic eruptions, storms and pollution (Hughes 2014), whilst the founding of urban Rome itself involved drainage of the low-lying land between the hills of the city via what became the Cloaca Maxima. Rome later spread north from the Capitoline Hill and across the Tiber floodplain there to become the most populous part of the city; the area became formally incorporated into the city in Augustan times. Nevertheless, the Romans appear to have been somewhat insouciant about flooding and did not greatly protect the area. In fact, extensive flood protection and embanking of the Tiber only took place in the late nineteenth century (Aldrete 2007). So, were Roman settlements elsewhere in Europe really sited to be consistent with flood risk?

There is now a growing body of quantitative research focusing on historical flooding, specifically estimating the magnitude, frequency, and timing of extreme historic discharges in Europe during the last millennium. These analyse documentary records, dated flood sediments, and climate records and reconstructions (Benito et al. 2004, 2015; Herget et al. 2014; Wetter et al. 2011; Toonen et al. 2015). Here we address different challenges: did extreme floods inundate historically developing urban areas? Were early urban developments well sited with respect to flooding? And, in the absence of records, is it possible to infer awareness of flood liability at such times? Furthermore, if early sites were relatively secure, does present-day flood liability reflect a change in flood frequency and magnitude resulting from historical catchment changes or changes in climate, or is increased risk simply a function of later incautious historical urban spread? To answer such questions, an exercise in flood modelling and flood extent mapping has been undertaken for a representative selection of twelve important Roman town sites in the UK, most of which have later developed into major towns and cities (Fig. 1 and Table 1).

\section{Methods}

A two-level approach was employed for each of the twelve sites, the objective being to use available data and readily adopted methods that may be applied to any archaeological site for which flood liability is in question. First, the extent of Roman settlements was obtained from archaeological surveys (archiuk.com), and then, using ARCGIS, site plans were superimposed onto current UK Environment Agency indicative flood maps showing the $0.1 \%$ annual flood extent (Environment Agency 2012a). This recurrence frequency was chosen to demonstrate the possible caution in Roman siting to be well clear of flooding. In practice the general nature of UK floodplains means that there is little spatial difference 


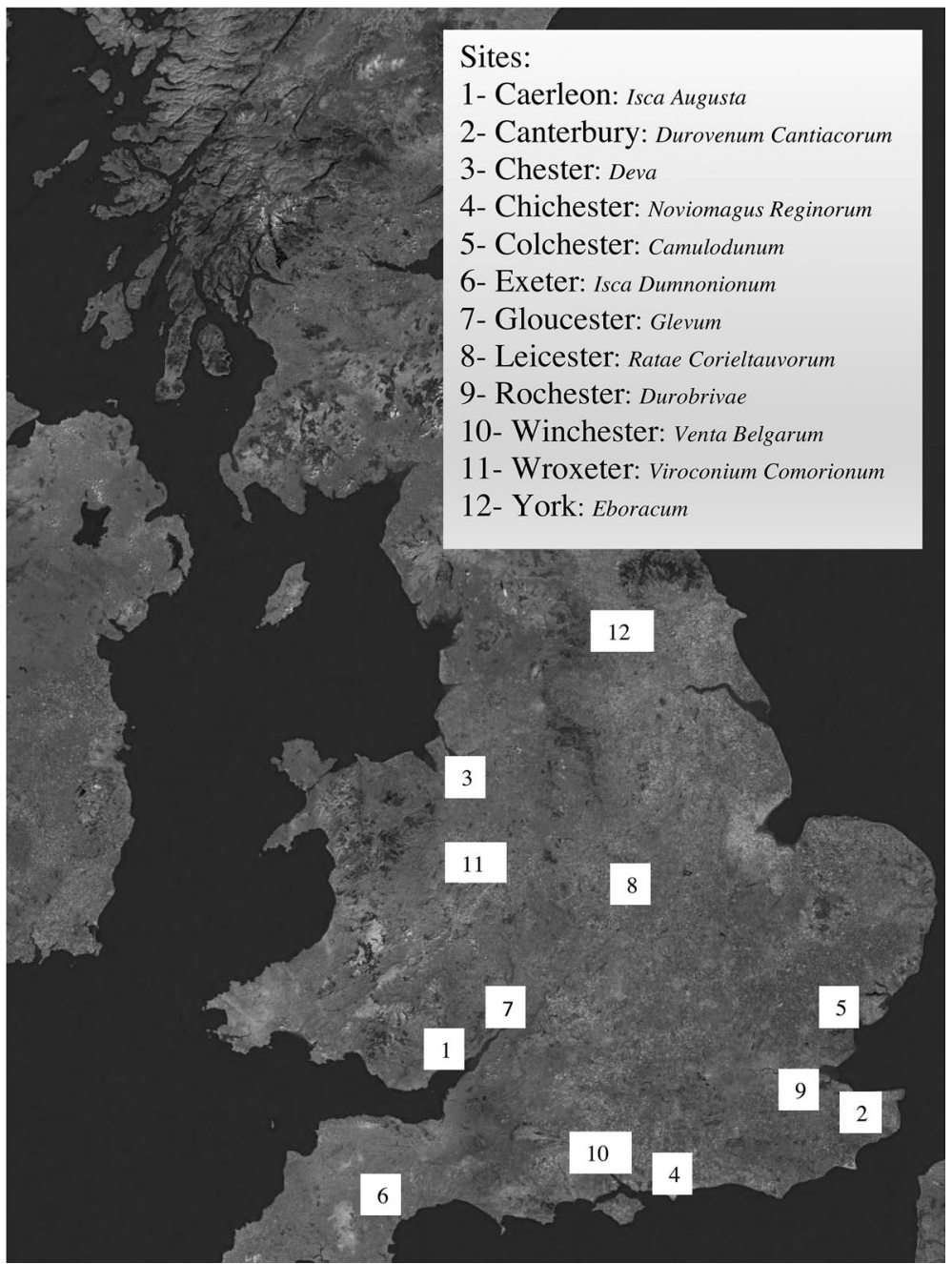

Fig. 1 Roman towns in Britain selected for analysis

between the extent of $1 \%$ and $0.1 \%$ flooding, both of which extend across valley floors to valley or terrace margins. A nominal $3 \times 3 \mathrm{~km}$ standard area was digitised to include the Roman sites, with minor adjustments to accommodate individual site conditions in each case. This gave an average sample area of $\left(9.76 \mathrm{~km}^{2}\right)$. The likely inundation extent was established (a) within the settled areas in Roman times, and (b) at the present-day including later urban development. Second, using the Agency's Flood Estimation Handbook methods (Baylis 1999; Robson and Reed 1999), catchment parameters were used to estimate extreme event hydrographs for the nearest upstream gauging station (Environment Agency 2012b). A sensitivity analysis was then undertaken to see the effect of using different parameter values on flood peaks and lag times. Such parameters include catchment soil wetness (which varies regionally), land cover, reservoirs and fraction urbanised. These were then adjusted to produce values that were likely to be representative of Roman times. 
Table 1 The 12 selected study sites and their rivers

\begin{tabular}{llll}
\hline Town & Roman name & Grid reference & River \\
\hline Caerleon & Isca Augusta & SO 345056 & Usk \\
Canterbury & Durovenum Cantiacorum & TR 115553 & Stour \\
Chester & Deva & SJ 409659 & Dee \\
Chichester & Noviomagus Reginorum & SU 871064 & Lavant \\
Colchester & Camulodunum & TL 992,261 & Colne \\
Exeter & Isca Dumnonionum & SS 936016 & Exe \\
Gloucester & Glevum & SO 844279 & Severn \\
Leicester & Ratae Corieltauvorum & SK 615124 & Soar \\
Rochester & Durobrivae & TQ 709530 & Medway \\
Winchester & Venta Belgarum & SU 467213 & Itchen \\
Wroxeter & Viroconium Comorionum & SJ 412144 & Severn \\
York & Eboracum & SE 568554(Ouse), SE & Ouse and \\
& & 612543 (Foss) & Foss con- \\
& & & fluence \\
\hline
\end{tabular}

\section{Results}

Figure 2 shows two of the sites analysed: York and Gloucester. Most of the Roman sites (8/12) are clear of the present-day $P=0.1 \%$ estimated flood limits, the exceptions being Chichester, Leicester, York, and Canterbury (Table 2). Chichester (Noviomagus Reginorum) was developed in the first and second centuries as a civitas tribal capital for the Regni built around a Roman fort; it seems likely to have been exceptionally liable to flooding. It appears to have been virtually abandoned in the third or early fourth centuries until the eighth. Canterbury (Durovenum) performed a similar function for the Cantiaci, but there appears also to have been an older Belgic enclosure on the site. Unlike Chichester, it enjoyed more continuous prosperity, enhanced with walls and with near-continuous occupation on into early Saxon times, especially as the royal and ecclesiastical capital of a Kentish kingdom. York (Eboracum) had a similarly extended occupation, initially as a Roman fort in the late first century, but then as a civitas and trading port with a prosperous extension across to the west side of the River Ouse. A late Roman decline has been ascribed to flooding (Russo 1998, p. 120), but whilst flooding did indeed occur, direct causal connection can only be tentative. Redevelopment subsequently took place in Saxon times until the Viking conquest of $866 \mathrm{CE}$.

Table 3 lists the total actual area (ha) at study sites around the Roman settlements that would be liable to extreme flooding (final column). This amounts to nearly a quarter in the case of Gloucester even though the Roman occupied portion of the sampled site there is unaffected. Apart from Wroxeter, the other Roman settlements have expanded considerably, especially with urban and industrial development from the nineteenth century onwards. Table 3 also lists sites in terms of peak river discharges as calculated using Flood Estimation Handbook methods, both for contemporary conditions, and for estimated Roman catchment conditions. Discharge magnitudes reflect river size, such that Chichester lies only on small drainages, whereas Gloucester lies alongside the Severn. Adjusting the likely catchment character differences makes very little difference to the flood estimates. 

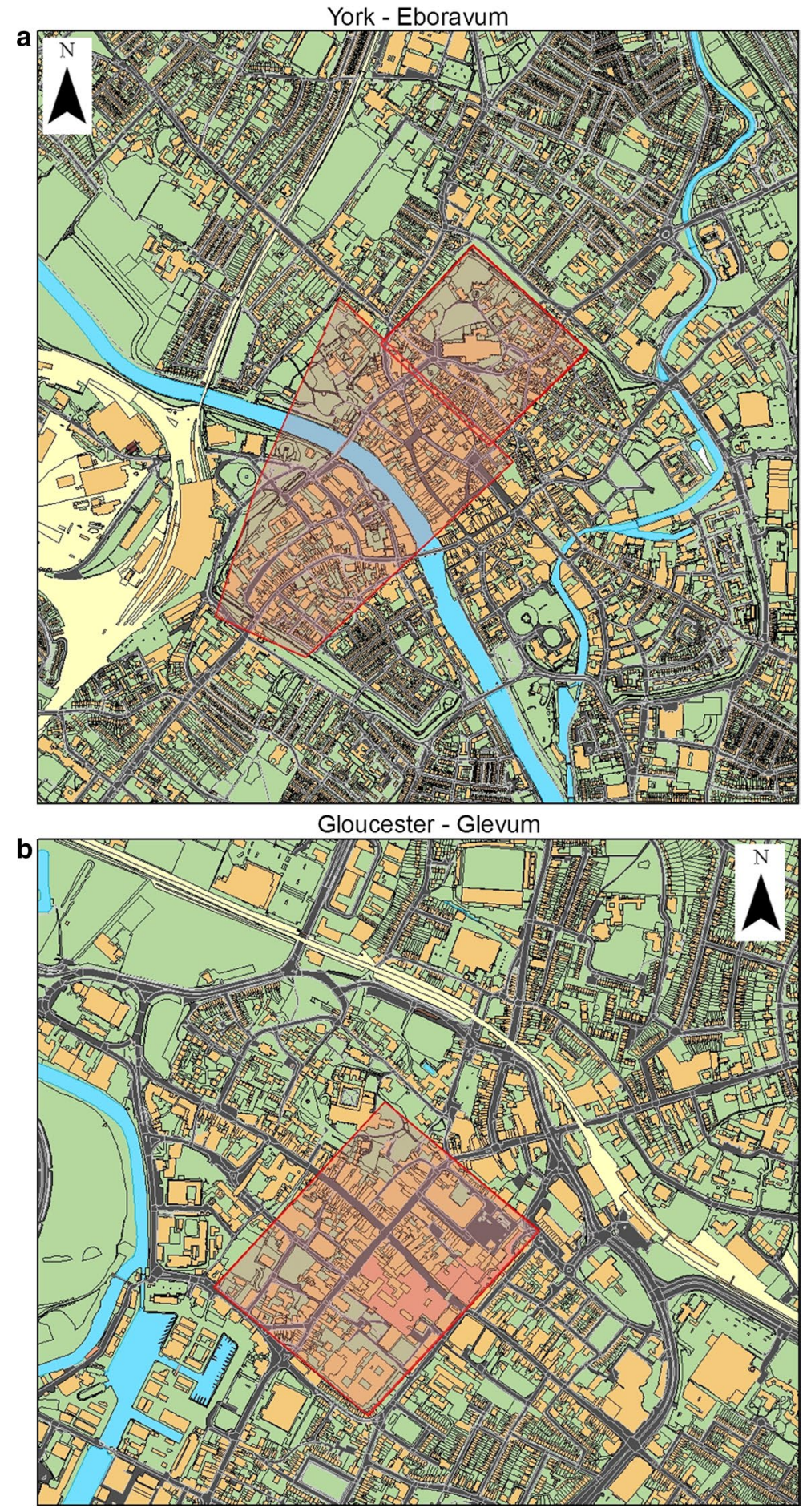

Fig. 2 The cities of York a and Gloucester b: The Roman occupied site (heavy shading) and the present urban landscape 
Table 2 Roman site inundation under current $0.1 \%$ unprotected flood peak estimation

\begin{tabular}{lll}
\hline & Roman site inundated (ha) & $\begin{array}{l}\text { Roman site } \\
\text { inundated } \\
(\%)\end{array}$ \\
\hline Chichester & 70 & 46.6 \\
Leicester & 30 & 25.0 \\
York & 20 & 13.3 \\
Canterbury & 5 & 5.0 \\
\hline
\end{tabular}

Table 3 Towns in ranked order (1-12) for their peak river flows $\left(\mathrm{m}^{3} / \mathrm{s}\right)$ for simulated Roman and actual contemporary conditions, and sample area flooded (ha) at extreme flows $(0.1 \%)$ under contemporary conditions

\begin{tabular}{|c|c|c|c|c|c|}
\hline \multirow[t]{2}{*}{ Ranking } & \multicolumn{2}{|l|}{ Roman } & \multicolumn{3}{|c|}{ Contemporary } \\
\hline & Site & Peak flow $\left(\mathrm{m}^{3} / \mathrm{s}\right)$ & $\overline{\text { Site }}$ & Peak flow $\left(\mathrm{m}^{3} / \mathrm{s}\right)$ & $\begin{array}{l}\text { Area flooded at } \\
\text { peak flow(ha) }\end{array}$ \\
\hline 1 & Gloucester & 1685.10 & Gloucester & 1808.70 & 244.87 \\
\hline 2 & Wroxeter & 1170.50 & Wroxeter & 1227.50 & 147.19 \\
\hline 3 & Chester & 929.80 & Chester & 961.00 & 118.65 \\
\hline 4 & Caerleon & 863.40 & Caerleon & 874.90 & 108.86 \\
\hline 5 & York* & 661.90 & York & 686.55 & 90.42 \\
\hline 6 & Rochester & 630.90 & Rochester & 676.20 & 88.11 \\
\hline 7 & Exeter & 587.00 & Exeter & 591.00 & 80.69 \\
\hline 8 & Leicester* & 182.80 & Leicester & 191.20 & 75.05 \\
\hline 9 & Canterbury* & 123.80 & Canterbury & 129.30 & 61.47 \\
\hline 10 & Colchester & 53.60 & Colchester & 57.60 & 60.96 \\
\hline 11 & Winchester & 39.90 & Winchester & 41.60 & 59.10 \\
\hline 12 & Chichester* & 21.50 & Chichester & 22.00 & 49.81 \\
\hline
\end{tabular}

*Denotes that a proportion of the Roman settlement at the site was probably liable to inundation at the time (see Table 2)

Instantaneous Flood Hydrographs (IFHs) were constructed for contemporary and Roman catchment states using a standard Environment Agency model (ReFH v.1). That modelled for York has an irregularity at the graph tail (Fig. 3). This represents a limitation in the ReFH v.1 model's inability to resolve large volume, long-duration $(>40 \mathrm{~h})$ urban flood scenarios as they exceed the maximum boundaries of the standard flood model equations on which the original iteration of the ReFH was based. It is understood that these limitations have since been addressed in the updated ReFH v. 2 model, as issued in 2015. This could provide scope for re-modelling following that outlined here; other modelling approaches could also be used, although neither would be likely to make a large difference to the hydrographs as a whole. The FEH approach to incorporating catchment parameter values representative of IFHs in Roman times involves some uncertainties in any case. Broadly, there are catchment parameters (e.g. altitude, catchment area, slope aspect) that are not likely to have altered historically. Others can be estimated with confidence (e.g. reservoir effects), but change in yet others are more difficult to quantify (e.g. rainfall, runoff, baseflow). Given the importance of the values assigned to these FEH parameters for deriving flood behaviour, extreme values for urban and rural flow regimes were implemented 
FEH ReFH Model Output: York (ouse) Roman

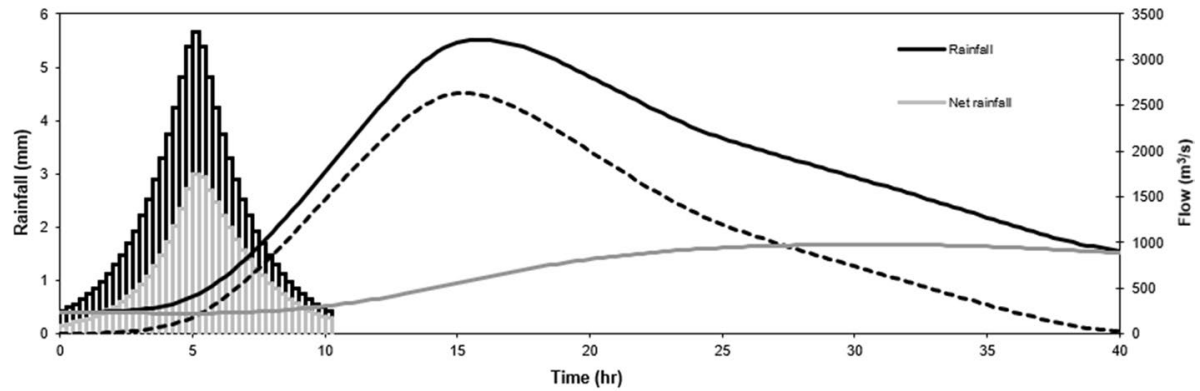

FEH ReFH Model Output: York (ouse) contemporary

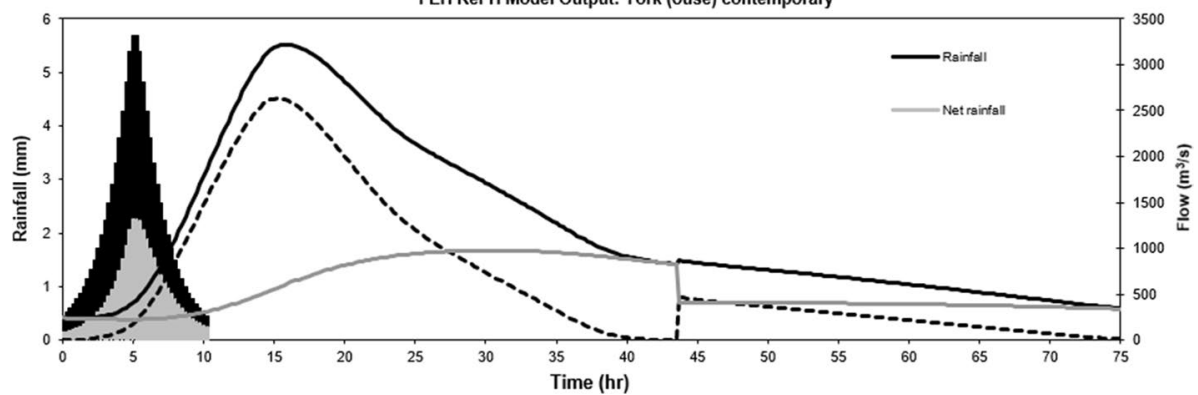

Fig. 3 Modelling outputs for the Ouse at York for Roman (top) and contemporary (bottom) conditions. The dark solid line represents total rainfall within a modelled catchment, the lighter grey line is net rainfall for effective surface flow and the dotted line is the average between the two

across all sites. Both the Ouse and Foss at York suggest that contemporary flood peaks are greater than in Roman times, but lag times differ as might be expected with urbanisation: flashier run-off regimes, shorter lag-times, and generally higher peak discharges. Nevertheless, York is now fifth in the ranking as opposed to third in the Roman rankings of the four Roman sites inundated, shown in Table 2. Chichester (Fig. 4) exhibits a similar flood hydrograph between Roman and contemporary settings. Urbanisation at the site appears not to have drastically affected the flood regime, yet it has gone from being the most settlement-inundated during Roman times, to the least in contemporary rankings in terms of total actual (ha) inundation. This may be attributed to relatively low urban development relative to other sites since Roman settlement.

\section{Discussion}

The reported results suggest relative immunity of initial Roman sites to flooding. However, some further considerations should be born in mind. First, there must be doubt as to whether long-term probability assessments based on assuming hydroclimatic constancy are sufficiently realistic. Büntgen et al. $(2011,2016)$ have demonstrated climatic variability over the last two millennia using proxy records based on tree ring analysis, with increasing variability in the late Roman period. They identify a Late Antiquity 'Little Ice Age', c.536-660 CE. There were also fluctuations within the Roman period as well as later 

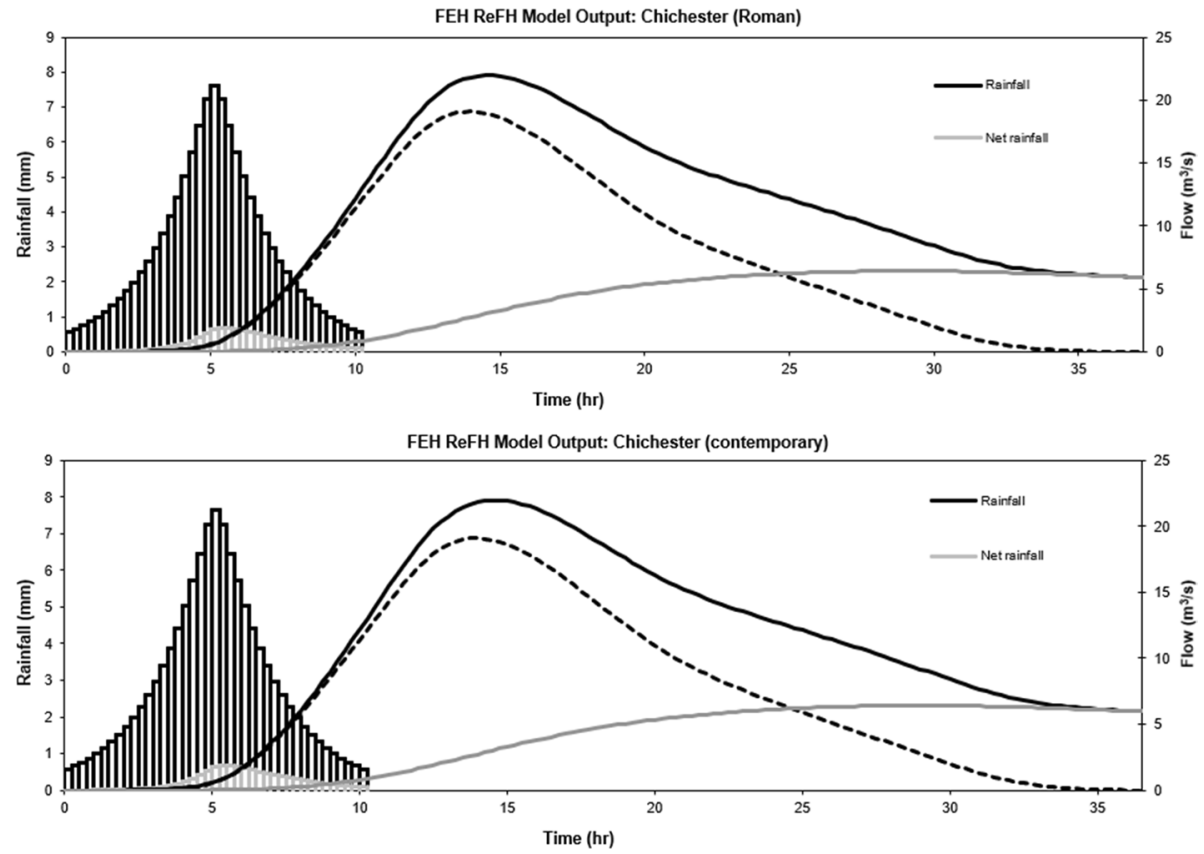

Fig. 4 Modelling outputs for Chichester for Roman (top) and contemporary (bottom) conditions

instability at the end of it (McCormack et al. 2012). Whilst it is not possible directly to infer inundation frequency directly from the climate proxy data used, independently derived flood data (Toonen et al. 2016) do show a paucity of extreme events in the early Roman period followed by an increase after c. 250 CE.

Extreme events in general group into short episodes of a few years and longer phases that last for decades or centuries. Probability estimates vary because of these periodicities, and according to the time periods and evidence used (Toonen et al. 2016). Although UK floodplains broadly constrain a range of extreme inundations topographically to similar extents, so that their spatial extent is over a narrow range, the probability values for broad valley floor flood occupancy are not historically constant and, so far to date, depend on short runs of numerical data. Considerable advances in palaeohydrology have been made in recent decades, using sedimentary records from rivers and lakes, and through the analysis of historical records, tree rings and speleothems (Wilhelm et al. 2018). This means that future analysis of the kind attempted here will benefit from a much greater understanding at least of likely discharge variations over the historical past.

Second, there have been post-Roman changes to the morphologies of both river channels and their floodplains in both England and across Europe, with aggradation in some places (generally at lowland sites) and river and terrace incision in others (generally upland locations) (Macklin et al. 2013; Brown et al. 2018). Deforestation across and since the Roman period (Kaplan et al. 2009), and then higher tillage erosion rates, have characterised many areas including southern and eastern parts of the UK (Van Ost et al. 2009). In the UK, medieval soil erosion under population and land pressure before the Black Death (1348-9 CE) added a blanket of fine sediment to floodplains and siltation within channels. Whether flood discharges greatly changed or not, this has led to the deposition of fine 
sediment across flood plains (Macklin et al., 2014; Pears et al. 2020). Thus, in the Nene valley, over $2 \mathrm{~m}$ of alluvial clays overlie Late Saxon or medieval ridge-and-furrow (Robinson 1992), whilst at York $9 \mathrm{~m}$ of sediment provide a record of flood sedimentation from the second century CE (Hudson-Edwards et al. 1999). Ground levels in cities themselves have become elevated as they have been repeatedly rebuilt on top of 'anthropogenic deposits', especially their wastes and remains of earlier buildings (Luberti 2018).

In the UK uplands to the north and west, several post-Roman periods of river incision occurred, thus reducing the lateral spread of floodwaters (Macklin et al. 2013). Whilst this incision has had limited effects on the Roman sites discussed here (mostly in lowland locations), this is not necessarily true of others for which current indicative flood limits would not be historically representative. What also remains unknown is the extent to which channel capacities have changed, thus altering the proportion of floodwaters being spilled across floodplain sites. This could well be an important factor (Sofia et al. 2020), as well as the post-Roman history of river engineering (Lewin 2010, 2013; van Dinter et al. 2017; Mandarino et al. 2020; Heritage and Entwhistle 2020).

Finally, improvements in flood modelling continue to be made (Neal et al. 2009, 2013) and verified against actual floodwater observations. With increasing precision in topographic definition (both estimated for the past as well the present) and hydraulic modelling, the inundation liability of sites will become better defined. Future work might firstly consider the impact that climatological variance is having on the rural and urban REF parameters and thus on potential inundation extents across return periods enhancing the results from the approach taken here.

\section{Conclusions}

Using Environment Agency standard industrial methods, we have presented an initial quantitative assessment of the flood susceptibility of Roman settlements. This suggests that the majority of the twelve locations studied were indeed well sited, the exceptions being Chichester, Leicester, York, and Canterbury. Varying the likely differences in catchment characteristics between now and then does not appear to have greatly altered this picture. The increased local levels of flood hazard today result from incautious urban expansion.

However, we also caution that probability level estimates are much affected by hydroclimatic fluctuations, with data non-stationarity and episodic changes now known to be evident over centuries to millennia. Local channel and floodplain morphologies in the UK have also been selectively modified in the last two millennia producing both sedimentation and river incision in different places. Morphologies have changed. Further detailed site studies beyond those undertaken here should be subjected to field checks to estimate morphological change, whilst probability estimates are likely to be improved with further development in modelling precision and historical flood history reconstruction using extended records.

Acknowledgements The authors would like to acknowledge the support of The University of Bristol Department of Geographical Sciences, The University College London Department of Earth Sciences and The EWS Academic Trust in the development of the work outlined in this paper.

Open Access This article is licensed under a Creative Commons Attribution 4.0 International License, which permits use, sharing, adaptation, distribution and reproduction in any medium or format, as long as you give appropriate credit to the original author(s) and the source, provide a link to the Creative Commons licence, and indicate if changes were made. The images or other third party material in this article 
are included in the article's Creative Commons licence, unless indicated otherwise in a credit line to the material. If material is not included in the article's Creative Commons licence and your intended use is not permitted by statutory regulation or exceeds the permitted use, you will need to obtain permission directly from the copyright holder. To view a copy of this licence, visit http://creativecommons.org/licenses/by/4.0/.

\section{References}

Aldrete GS (2007) Floods of the Tiber in ancient Rome. Johns Hopkins University Press, Baltimore Bayliss A (1999) Flood estimation handbook, 5: catchment descriptors. Institute of Hydrology, Oxford Benito G, Brázdil R, Herget J, Machado MJ (2015) Quantitative historical hydrology in Europe. Hydrol Earth Syst Sci 19:3517-3539. https://doi.org/10.5194/hess-19-3517-2015

Benito G, Lang M, Barriendos M, Llasat C, Francés F, Ouarda T, Thorndycraft VR, Enzel Y, Bardossy A, Coeur D, Bobée B (2004) Use of systematic, paleoflood and historical data for the improvement of flood risk estimation. Rev Sci Methods Nat Hazards 31:623-643

Brown AG, Lespez L, Sear DA, Macaire J-J, Houben KK, Brazier RE, Van Oost K, Pears B (2018) Natural versus anthropogenic streams in Europe: history, ecology and implications for restoration, river re-wilding and riverine ecosystem services. Earth Sci Rev 180:185-205. https://doi.org/10.1016/j. earscirev.2018.02.001

Büntgen U et al (2011) 2500 years of European climate variability and human susceptibility. Science 331:578-582

Büntgen U et al (2016) Cooling and societal change during the late antiquity little ice age from 536 to around 660 AD. Nat Geosci 9:231-236. https://doi.org/10.1038/ngeo2652

Envionment Agency (2012a) Flood Maps. (Retrieved June 10, 2012, from https://www.environmen t-agency.gov.uk)

Environment Agency (2012b) HiFlows UK. (Retrieved June 10, 2012, from https://www.environmen t-agency.gov.uk/hiflows)

Herget J, Roggenkamp T, Krell M (2014) Estimation of peak discharges of historical floods Hydrol. Earth Syst Sci 18:4029-4037. https://doi.org/10.5194/hess-18-4029-2014

Heritage G, Entwhistle N (2020) Impacts of river engineering on river channel behaviour: implications for managing downstream flood risk. Water 12:1355. https://doi.org/10.3390/w12051.1355

Hudson-Edwards KA, Macklin MG, Finlayson R, Passmore DG (1999) Medieval lead pollution in the river Ouse at York. England J Arch Sci 26:809-819. https://doi.org/10.1006/jasc.1998.0357

Hughes JD (2014) Environmental problems of the Greeks and Romans (2nd Edition). Johns Hopkins University Press, Baltimore

Kaplan JO, Krumhardt KM, Zimmermann N (2009) The prehistoric and preindustrial deforestation of Europe. Quatern Sci Rev 28:3016-3034. https://doi.org/10.1016/j.quascirev.2009.09.028

Lewin J (2010) Medieval Environmental Impacts and Feedbacks: the Lowland Floodplains of England and Wales. Geoarch 25:267-311. https://doi.org/10.1002/gea.20308

Lewin J (2013) Enlightenment and the GM floodplain. Earth Surf Proc Landf 38:17-29. https://doi. org/10.1012/esp.3230

Luberti GM (2018) Computation of modern anthropogenic-deposit thickness in urban areas: a case study in Rome Italy. Anthrop Rev 5:2-27. https://doi.org/10.1177/205301961875252

McCormick M et al (2012) Climate change during and after the Roman Empire: Reconstructing the past from scientific and historical evidence. J Interdisc His 43:169-220

Macklin MG, Lewin J, Jones AF (2013) River entrenchment and terrace formation in the UK Holocene. Quat Sci Rev 76:194-206. https://doi.org/10.1016/j.quascirev.2013.05.026

Macklin MG, Lewin J, Jones AF (2014) Anthropogenic alluvium: an evidence-based meta-analysis for the UK Holocene. Anthropocene 6:26-38. https://doi.org/10.1016/j.ancene.2014.03.003

Mandarino A, Luino F, Turconi L, Faccini F (2020) Urban geomorphology of a historical city straddling the Tanaro River (Alessandria, NW Italy). J Maps. https://doi.org/10.1080/17445647.2020.1746420

Neal JC, Bates PD, Fewtrell TJ, Hunter NM, Wilson MD, Horrit MS (2009) Distributed whole city water level measurements from the Carlisle 2005 urban flood event and comparison with hydraulic model simulations. J Hydrol 368:42-55. https://doi.org/10.1017/j.hydrol.2009.01.026

Neal JC, Keef C, Bates PD, Beven K, Leedal D (2013) Probabilistic flood risk mapping inlcuding spatial dependence. Hydr Proc 27:1349-1363. https://doi.org/10.1002/hyp.9572

Pears B, Brown AG, Toms PS, Wood J, Sanderson D, Jones R (2020) A sub-centennial-scale optically stimulated luminescence chronology and late Holocene flood history from a temperate river confluence. Geology. https://doi.org/10.1130/G47079.1 
Pierik HJ, van Lanen RJ (2019) Roman and early-medieval habitation patterns in a delta landscape: The link between settlement elevation and landscape dynamics. Quat Int 501:379-392. https://doi. org/10.1016/j.quaint.2017.03.010

Robinson M (1992) Environment, archaeology and alluvium on the river gravels of the South Midlands. In: Needham S, Macklin MG (eds) Alluvial archaeology in Britain. Oxbow, Oxford, pp 197-208

Robson A, Reed D (1999) Flood estimation handbook, 3: statistical procedures for flood frequency estimation. Insitute of Hydrology, Oxford

Russo G (1998) Town origins and development in early England, c.400-950 A.D. Greenwood Press, London

Sofia G, Nikolopoulos EI (2020) Floods and rivers: a circular causality perspective. Nat Sci Rep. https:// doi.org/10.1038/s1598-020-61533-x

Toonen WHJ (2015) Flood frequency analysis and discussion of non-stationarity of the lower rhine flooding regime (AD 1350-2011): using discharge data, water level measurements and historical records. J Hydrol 528:490-502. https://doi.org/10.1016/j.hydrol.2015.06.014

Toonen WHJ, Middelkoop H, Konijnendijk TYM, Macklin MG, Cohen KM (2016) The influence of hydroclimatic variability on flood frequency in the lower rhine. Earth Surf Proc landf 41:1266-1275. https:// doi.org/10.1002/esp.3953

Van Dinter M, Cohne KM, Hoek WZ, Stouthamer E, Jansma E, Niddelkoop H (2017) Late Holocene lowland fluvial archives and geoarchaelogy: utrecht's case study of rhine river abandonment under roman and medieval settlement. Quat Sci Rev 166:227-265. https://doi.org/10.1016/j.quascirev2016.12.003

Van Ost K, Cerdan O, Quine TA (2009) Accelerated sediment fluxes by water and tillage erosion on European agricultural land. Earth Surf Proc Land 34:1625-1634. https://doi.org/10.1002/esp.1852

Wetter O, Pfister C, Weingartner R, Luterbacher J, Reist T, Trösch J (2011) The largest floods in the high rhine basin since 1268 assessed from documentary and instrumental evidence. Hydr Sci J 56:733-758. https://doi.org/10.1080/02626667.2011.583613

Wilhelm B, Cánovas JAB, Macdonald N et al (2018) Interpreting historical, botanical and geological evidence to aid preparations for future floods. WIRES Water. https://doi.org/10.1002/wat2.1318

Publisher's Note Springer Nature remains neutral with regard to jurisdictional claims in published maps and institutional affiliations. 